\title{
Ekstrak Daun Kersen (Muntingia calabura L.) Mencegah Kerusakan Mukosa Duodenum Tikus Wistar Yang Dipapar Etanol 40\%
}

\author{
Moh. Iqbal Setiawan, ${ }^{1}$ Arum Kartikadewi, ${ }^{2}$ Afiana Rohmani, ${ }^{2}$ Noor Yazid ${ }^{2}$ \\ ${ }^{1}$ Mahasiswa S1 Fakultas Kedokteran Universitas Muhammadiyah Semarang \\ ${ }^{2}$ Staff Pengajar Fakultas Kedokteran UniversitasMuhammadiyah Semarang \\ Email: iqbal.unimus@gmail.com,
}

\begin{abstract}
Ethanol causes duodenal injury caused by oxidative stress due to free radicals. The negative effects of free radicals can be neutralized by antioxidants. Kersen leaves have a high antioxidant effect. The aim of this study was to determine the effect of administration of Kersen extract on the histopathological picture of rat's duodenal induced by $40 \%$ ethanol. The study was Post test only group design study. The sample was consisted of 24 male rats divided into 4 groups. K- was given a placebo aquadest $1.8 \mathrm{ml} / 200 \mathrm{~g} /$ day. The $\mathrm{K}+$ group was given $40 \%$ ethanol at a dose of $1.8 \mathrm{ml} / 200 \mathrm{~g} /$ day. P1 group was given 500mg / KgBB leaves extract of 60 minutes continued with $40 \%$ alcohol 60 minutes after treatment. P2 group was given $750 \mathrm{mg} / \mathrm{KgBB}$ leaf extract 60 minutes continued with $40 \%$ alcohol 60 minutes after treatment. Treatment in each group for 30 days. On the $31^{\text {st }}$ day, rats were terminated and a duodenal histopathological preparation was made and the degree of the damage was measured according by the Barthel-Manja score. The mean damage was analyzed by the One way ANOVA test continued with the Post hoc LSD Test. The mean duodenal damage score were $\mathrm{K}-=0.76, \mathrm{~K}+=2.60, \mathrm{P} 1=0.60$ and $\mathrm{P} 2=0.84(\mathrm{p}<0.001)$. The difference of the duodenal mucosal damage degree were in $\mathrm{K}+$, P1, P2 compared to K- respectively $(\rho<0.001)$; $(\rho: 0,491)$; $(\rho: 0.729)$. The administration of $500 \mathrm{mg} / \mathrm{KgBB}$ dose was provides cytoprotective effect on duodenal mucosa of rats induced by $40 \%$ ethanol.
\end{abstract}

Keywords: ethanol, kersen leaf extract (Muntingia calabura L.), histopathological features of duodenum

\begin{abstract}
Abstrak
Etanol menimbulkan cedera duodenum yang disebabkan stres oksidatif akibat radikal bebas.. Efek buruk radikal bebas dapat dinetralisir oleh antioksidan. Daun Kersen mempunyai efek antioksidan yang tinggi. Penelitian ini bertujuan mengetahui pengaruh pemberian ekstrak daun kersen terhadap gambaran histopatologi duodenum tikus wistar yangdiinduksi etanol 40\%. Penelitian ini menggunakan rancangan Post test only group design. Sampel terdiri dari 24 tikus wistar jantan yang dibagi 4 kelompok. K- diberi placebo aquadest $1.8 \mathrm{ml} / 200 \mathrm{~g} / \mathrm{hari}$. Kelompok K+ diberi etanol $40 \%$ dosis $1.8 \mathrm{ml} / 200 \mathrm{~g} /$ hari. Kelompok P1 diberi ekstrak daun kersen $500 \mathrm{mg} / \mathrm{KgBB}$ selang 60 menit diberi etanol 40\%. Kelompok P2 diberi ekstrak daun kersen $750 \mathrm{mg} / \mathrm{KgBB}$ selang 60 menit diberi etanol $40 \%$. Perlakuan pada tiap kelompokselama 30 hari. Pada hari ke 31 tikus diterminasi dan dibuat sediaan histopatologi duodenum. Gambaran derajat kerusakan duodenum diperiksa dengan skor Barthel-Manja. Rerata kerusakan dianalisis dengan Uji One way anova dan Uji Post hoc Lsd. Rerata skor kerusakan duodenum K-=0.76,K+=2.60, $\mathrm{P} 1=0.60$ dan $\mathrm{P} 2=0.84$ ( $\mathrm{p}<0.001)$. Perbedaan Derajat kerusakan mukosa duodenum pada K+, P1, P2 dibanding Kberturut-turut $(\rho<0.001)$; $(\rho: 0.491)$; $(\rho: 0.729)$. Pemberian dosis $500 \mathrm{mg} / \mathrm{KgBB}$ mampu memberikan efek sitoprotektif pada mukosa duodenum tikus wistar yang diinduksi etanol $40 \%$.
\end{abstract}

Kata kunci: etanol, ekstrak daun kersen(Muntinga calabura L.), gambaran histopatologi duodenum. 


\section{PENDAHULUAN}

Jumlah konsumsi alkohol di seluruh dunia selalu mengalami peningkatan setiap tahunnya. World Health Organization memperkirakan sekitar 64 juta orang di seluruh dunia merupakan pecandu alkohol. Sementara itu di Indonesia, hasil Riskesdas pada tahun 2018 menunjukkan bahwa proporsi konsumsi minuman beralkohol mencapai $3.3 \%$ atau hampir 8 juta orang ${ }^{1}$. Hal ini kemudian menjadi suatu permasalahan kesehatan yang penting karena konsumsi alkohol akan menimbulkan berbagai penyakit, salah satunya adalah ulkus duodenum. Bersama dengan ulkus gaster, kedua penyakit ini diperkirakan menyerang sekitar 5-10\% populasi duniadengan peningkatan $0.1-0.3 \%$ setiap tahunnya ${ }^{2}$. Kedua penyakit ini juga berkaitan dengan sekitar 300 ribu kematian setiap tahunnya ${ }^{3}$.

Alkohol (etanol) yang dikonsumsi akan diubah menjadi asetaldehid oleh enzim ADH di dalam lambung dan duodenum. Di dalam sel, asetaldehid dalam jumlah besar dapat mengganggu peoses transpor elektron, sehingga meningkatkan produksi Reactive Oxygen Species (ROS), yaitu semacam gugus radikal bebas. Molekul ini dapat menyebabkan kerusakan jaringan yang melibatkan fungsi mitokondria yang akhirnya mengganggu produksi protein dan lipid oleh DNA di dalam $\operatorname{sel}^{4}$.Beberapa studi yang telah dilakukan menunjukkan bahwa etanol menyebabkan kerusakan integritas mukosa epitel, menginduksi pelepasan sitokin inflamasi, dan menurunkan sintesis prostaglandin. Ketiga hal tersebut menyebabkan terjadinya jejas pada epitel duodenum. Beberapa bentuk jejas yang dapat teramati adalah deskuamasi epitel, erosi mukosa, dan adanya ulkus 5 .

Berdasarkan patogenesis tersebut, pemberian anti oksidan untuk mengatasi paparan radikal bebas menjadi suatu hal yang dapat diterima secara konseptual. Pemberian anti oksidan dapat mengurangi radikal bebas, sehingga proses patogenesis tersebut di atas menjadi berkurang. Berbagai tanaman diketahui memiliki molekul yang bersifat anti oksidan, salah satunya adalah daun kersen ${ }^{6}$.

Daun kersen (Muntingia calabura L.)dilaporkan memiliki banyak kegunaan karena kandungan senyawa antioksidan seperti flavonoid, tannin, polifenol, dan saponin ${ }^{7}$.Berbagai penelitian telah dilakukan untuk mengetahui manfaat dari daun kersen. 
Penelitian yang dilakukan Murti dkk (2016) mengkonfirmasi bahwa ekstrak daun kersen dosis $\quad 500 \mathrm{mg} / \mathrm{KgBB}$ dan $\quad 750 \mathrm{mg} / \mathrm{KgBB}$ menghasilkan perbedaan yang bermakna pada gambaran mikroskopis hepar yang diinduksi etanol $40 \%$ dan soft drink. ${ }^{12}$ Penelitian lain yang dilakukan oleh Ninditya (2016) mengenai pengaruh ekstrak daun kersen terhadap ginjal tikus menyatakan bahwa pada dosis $500 \mathrm{mg} / \mathrm{KgBB}$ ekstrak daun kersen mampu menurunkan jumlah kerusakan tubulus ginjal tikus wistar yang diinduksi etanol dan softdrink ${ }^{8}$.

Berdasarkan uraian di atas, dapat dilihat bahwa penyalahgunaan konsumsi alkohol merupakan salah satu masalah kesehatan yang sangat penting untuk diperhatikan karena dapat menyebabkan peningkatan produksi radikal bebas yang dapat menimbukan kerusakan mukosa hingga ulkus pada organ duodenum. Kerusakan mukosan duodenum akibat paparan alkohol tersebut perlu dilakukan upaya pencegahan. Daun kersen merupakan salah satu tanaman yang memiliki efek penangkal radikal bebas di berbagai organ, sehingga diduga kandungan antioksidan tanaman ini juga mampu mengatasi permasalahan pada duodenum yang terpapar etanol secara kronis. Tujuan penelitian adalah mengetahui efek pengaruh pemberian ekstrak daun kersen terhadap gambaran histopatologi duodenum tikus Wistar yang diinduksi etanol $40 \%$.

\section{METODE}

\section{Pemeliharaan Hewan Coba}

Jenis penilitian yaitu True Experimental dengan Post test only group design yang dilakukan pada tikus wistar jantan yang berusia 6-8 minggu, berat 150200 gram, sehat dan tidak mempunyai kelainan anatomi. Tikus didapatkan dari laboratorium Biologi fakultas Fakultas Matematika dan Ilmu Pengetahuan Alam (FMIPA) Universitas Negeri Semarang Universitas Negeri Semarang(UNNES). Sampel terdiri dari 24 tikus wistar jantan yang dibagi dalam 4 kelompok secara randomisasi. Kelompok terdiri atasK- diberi placebo aquadest $1.8 \mathrm{ml} / 200 \mathrm{~g} / \mathrm{hari}, \mathrm{K}+$ diberi etanol $40 \%$ dosis $1,8 \mathrm{ml} / 200 \mathrm{~g} /, \mathrm{P} 1$ diberi etanol $40 \%$ sesudah 60 menit pemberian ekstrak daun kersen $500 \mathrm{mg} / \mathrm{KgBB}$ dan P2 diberi etanol $40 \%$ sesudah 60 menit ekstrak daun kersen $750 \mathrm{mg} / \mathrm{KgBB}^{4}$. Perlakuan selama 30 hari, lalu tikus diterminasi pada hari ke-31. 
Peneletian di lakukan di Laboratorium FMIPA UNNES.

\section{Pengambilan Sediaan Histopatologi}

Dilakukan proses pengambilan sampel organ duodenum tikus wistars pada hari ke-31 selanjutnya dibuat preparat histolopatologi dengan metode blok parafin dengan pengecatan Hematoxilin eosin(HE). Pembuatan preparat dilaksanaka di Rumah Sakit Roemani Muhammadiyah Semarang dan pembacaan preparat dilakukan di Laboratorium Biomedik Fakultas Kedokteran Universitas Muhammadiyah Semarang. Pengamatan gambaran histopatologi duodenum tikus wistar dilakukan menggunakan mikroskop trinokuler dengan perbesaran 100x dalam 5 lapang pandang setiap sampel duodenum tikus wistar. Pengamatan dilakukan oleh dokter spesialis Patologi Anatomi. Skor kerusakan mukosa duodenum dengan kriteria Barthel-Manja9 ${ }^{9}$ Rerata derajat kerusakan mukosa duodenum dianalisis menggunakan Uji One way anova dan Uji Post hoc Lsd.

\section{Ekstraksi Daun Kersen}

Pembuatan ekstrak daun kersen menggunakan metode maserasi menggunakan pelarut etanol 97\%. Daun kersen yang dipilih yaitu daun yang hijau dan tua, tidak terkena hama atau yang tidak rusak. Daun-daun dikumpulkan lalu dicuci dan angin-anginkan pada suhu ruang lalu di oven dengan suhu $60^{\circ} \mathrm{C}$ selama 24 jam. Daun yang telah kering dihaluskan dengan mesin grinding hingga halus. Serbuk daun kersen ditimbang 150gram lalu dimasukkan kedalam erlenmeyer ukuran satu liter. Dituangkan etanol $600 \mathrm{ml}$ ke dalam erlenmeyer, dihomogenkan dengan alat shaker inkubator selama 60 menit atau hingga benar-benar tercampur. Filtrat daun kersen disaring dengan kertas saring diulangi 5 kali. Dilakukan proses evaporasi untuk memisahkan larutan etanol dengan zat-zat aktif yangada didalam ekstrak. Hasil penyaringan dipekatkan dengan rotatory evaporator pada suhu temperatur $65-70^{\circ} \mathrm{C}$ selama dua jam. Ekstrak selanjutnya dilakukan uji analisis kadar fitokimia di Laboratorium FMIPA UNNES

Penelitian ini dilakukan sesuai ethical clearance dari Komisi Etik Penelitian Kesehatan Fakultas Kedokteran UNIMUS dengan nomor terbit 094/EC/FK/2019. 
HASIL

Hasil ekstraksi serbuk daun kersen diambil sebanyak 150 gram dicampur etanol 97\% sebanyak $600 \mathrm{ml}$ menghasilkan ekstrak kental $\quad 16.404 / 150 \operatorname{gr}^{10}$.Setelah diuji kualitatif, didapatkan ekstrak daun kersen mengandung saponin, flavonoid, tanin, alkaloid, fenolik, terpenoid, steroid, dan flavonoid quecertin. Kandungan yang paling dominan adalah quercetin sebanyak 1.5 $\mathrm{mg} / 16.404$ gr.

Hasil analisis kadar fitokimia ekstrak daun kersen terlihat pada tabel 1 .

Tabel 1 Hasil Analisis Kadar Fitokimia Ekstrak Daun Kersen

\begin{tabular}{cccc}
\hline No & Parameter Uji & Hasil & Keterangan \\
\hline 1. & Saponin & + & $\begin{array}{c}\text { Terbentuk busa yang tidak hilang } \\
\text { selama lebih dari 1 menit }\end{array}$ \\
\hline 2. & Flavonoid & + & Terbentuk warna merah \\
\hline 3. & Tanin & + & Terbentuk warna hitam kehijauan \\
\hline 4. & Alkaloid & + & Terbentuk endapan putih \\
\hline 5. & Fenolik & + & Terbentuk warna hijau-ungu \\
\hline 6. & Terpenoid & - & Tidak terbentuk warna merah/pink \\
\hline 7. & Steroid & + & Terbentuk warna biru/hijau \\
\hline 8. & Flavonoid & $1.5 \mathrm{mg}$ Quersetin & \\
\hline
\end{tabular}

Data pengamatan berupa nilai

rerata kerusakan dari masing-masing

kelompok yang dibagi dalam skor kerusakan integritas mukosa duodenum. Skor kerusakan mukosa menggunakan Indeks Barthel Manja, yaitu skor 0 bila tidak ada perubahan patologis; skor 1 bila ada deskuamasi epitel; skor 2 bila ada erosi permukaan epitel; dan skor 3 bila ada ulserasi epitel. Terlihat pada tabel 2. Hasil penelitian mengenai pengaruh ekstrak daun kersen terhadap gambaran histopatologi duodenum tikus wistar yang kemudian diinduksi etanol $40 \%$ terlihat pada gambar.

Tabel 3 Rerata dan Uji Beda Rerata Skor Kerusakan Mukosa duodenum

\begin{tabular}{|c|c|c|c|c|c|c|}
\hline \multirow[t]{2}{*}{ Kelompok } & \multirow[t]{2}{*}{ Mean \pm SD } & \multirow[t]{2}{*}{ Nilai $p$} & \multicolumn{4}{|c|}{ Post hoc LSD } \\
\hline & & & $\mathrm{K}-$ & $\mathrm{K}+$ & $\mathrm{P} 1$ & $\mathrm{P} 2$ \\
\hline $\mathrm{K}-$ & $0.76 \pm 0,26$ & \multirow{4}{*}{$<0.001 *$} & - & $<0.001 * *$ & 0.491 & 0.729 \\
\hline $\mathrm{K}+$ & $2.60 \pm 0,24$ & & $<0.001 * *$ & - & $<0.001 * *$ & $<0.001 * *$ \\
\hline $\mathrm{P} 1$ & $0.60 \pm 0,24$ & & 0.491 & $<0.001 * *$ & - & 0.306 \\
\hline $\mathrm{P} 2$ & $0.84 \pm 0,48$ & & 0.729 & $<0.001 * *$ & 0.306 & - \\
\hline
\end{tabular}

Tabel 3. Bintang satu (*) yaitu menggunakan Uji One way anova $\rho<0.05$ dan bintang dua (**) menggunakan Uji post hoc Lsd $(\rho<0.05)$; K-yaitu Kelompok kontrol negatif, diberi placebo aquadest $1.8 \mathrm{ml} / 200 \mathrm{~g} /$ haritanpa diberi ekstrak daun kersen maupun etanol $40 \%$. K+ adalah Kelompok kontrol positif, diberi etanol tanpa pemberian ekstrak daun kersen.P1 adalah Kelompok perlakuan 1, diberi ekstrak daun kersen dosis $500 \mathrm{mg} / \mathrm{KgBB}$ dan etanol 40\%.P2 adalah kelompok Perlakuan 2, diberi ekstrak daun kersen dosis 750mg/KgBB dan etanol $40 \%$. 
Pada uji One way anova tabel 3 didapatkan perbedaan signifikan dari seluruh kelompok dengan nilai $\mathrm{p}<0.001$. Sehingga dilanjutkan menggunakan uji beda Post hoc LSD (Least Significant Different). Hasil uji beda rerata antar kelompok didapatkan derajat kerusakan duodenum pada $\mathrm{K}+$

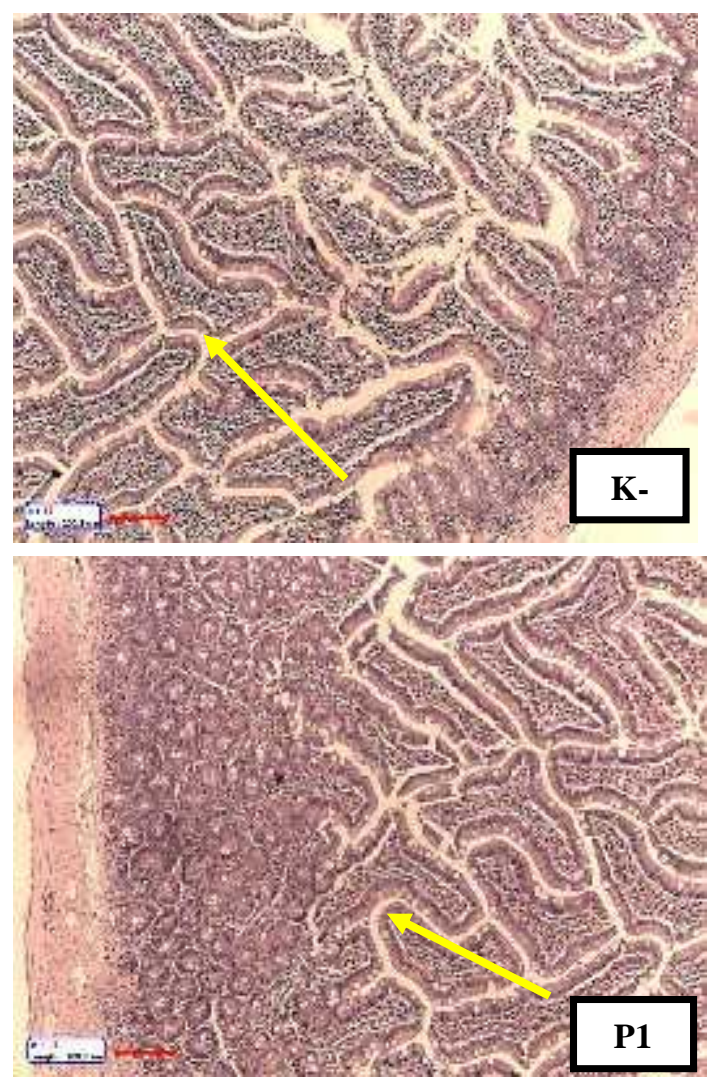

berbeda bermakana dibanding K$(\rho:<0.001)$, Pada kelompok yang diberi ekstrak daun kersen dosis 500mg/KgBB(P1) dan dosis $750 \mathrm{mg} / \mathrm{KgBB} \quad(\mathrm{P} 2)$ derajat kerusakan duodenum tidak berbeda bermakna dengan tikus normal $(\mathrm{K}-) \quad(\rho$ : $0.491)$ dan $(\rho: 0.729)$.
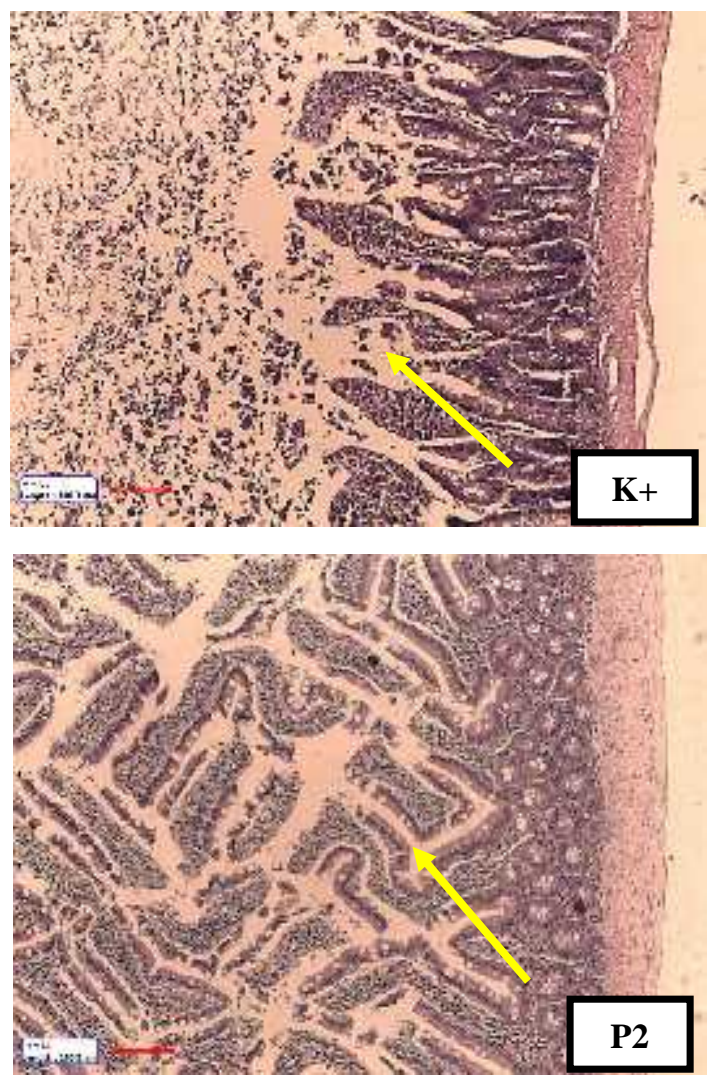

Gambar 1. Gambaran hitopatologi Mukosa Duodenum tikus Wistar dengan Perbesaran 100x Gambaran histopatologi duodenum antar kelompok. Dari gambar dapat dilihat rerata skor masing masing kelompok. Kelompok kontrol negatif (K-) memperlihatkan kesan normal,tidak didapatkan perubahan patologik pada epitel dan vili-vili duodenum dengan rerata kerusakan 0.76 . Kelompok kontrol positif $(\mathrm{K}+)$ didapatkan gambaranerosi pada separuh mukosa dan vili duodenum dengan rerata kerusakan 2.60. Kelompok perlakuan 1(P1) memperlihatkan kesan normal,tidak didapatkan perubahan patologik pada epitel dan vili-vili duodenum rerata kerusakan 0.60. Kelompok perlakuan 2 (P2) memperlihatkan kesan normal,tidak didapatkan perubahan patologik pada epitel dan vili-vili duodenum (rerata kerusakan 0.84) 


\section{PEMBAHASAN}

Penelitian pengaruh pemberian ekstrak daun kersen terhadap gambaran histopatologi duodenum tikus ini menggunakan sampel sebanyak 24 ekor tikus Wistar jantan, yang dibagi dalam 4 kelompok, tiap kelompok terdiri dari 6 ekor. Tikus (Rattus norvegicus) albino adalah hewan yang paling sering digunakan sebagai model dalam penelitian biomedis.Galur wistar ideal sebagai hewan coba untuk berbagai tujuan penelitian karena dapat mewakili sistem biologis mammal dan memiliki sistem faal yang mirip dengan manusia. ${ }^{11,12}$ Pemilihan tikus jantan digunakan dengan alasan mencit jantan tidak mengalami siklus estrus sehingga sampel menjadi homogen, mudah dikendalikan dan hasilnya diharapkan akan lebih akurat. $^{13}$

Etanol sebagai zat penting dalam alkohol bersifat mudah larut dalam air dan lemak sehingga etanol langsung diserap kedalam usus melalui difusi pasif. ${ }^{14}$ etanol dikonsumsi oleh tubuh sekitar $80 \%$ diserap oleh duodenum, hal tersebut dapat menimbulkan kerusakan mukosa duodenum berupa erosi mukosa hingga terjadi sebuah ulkus. ${ }^{15}$ Hal tersebut menjadi salah satu alasan penggunaan etanol sebagai penginduksi tukak pada duodenum. Pemilihan dosis etanol $40 \%$ sebagai induksi duodenum berdasarkan PERMENKES Nomor 86 mengenai minuman keras yang menyatakan bahwasannya dosis tersebut termasuk dalam golongan tertinggi jenis minuman berakohol tetapi bukan obat yang dikonsumsi manusia ${ }^{16}$ Pemberian dosis etanol dikonversikan dari manusia dewasa dengan berat badan $70 \mathrm{~kg}$ pada tikus dengan berat $200 \mathrm{~g}$ dengan tabel konversi dosis Pages dan Barnes sehingga ditemukan dosis yang sesuai untuk tikus Wistar jantan yaitu $1.8 \mathrm{ml} / 200 \mathrm{~g} /$ hari. $^{8}$

Pembuatan ekstrak daun kersen pada penelitian ini menggunakan metode maserasi. Proses maserasi sangat menguntungkan dalam isolasi senyawa bahan alam karena selain murah dan mudah dilakukan, dengan perendaman sampel tumbuhan akan terjadi pemecahan dinding dan membran sel akibat perbedaan tekanan antara di dalam dan di luar sel, sehingga metabolit sekunder yang ada dalam sitoplasma akan terlarut dalam pelarut organik dan ekstraksi senyawa akan sempurna karena dapat diatur lama perendaman yang dilakukan. Pelarut yang digunakan pada penelitian ini adalah etanol. Pemilihan pelarut etanol didasarkan pada tingkat keamanan dan kemudahan saat diuapkan serta sifatnya yang mampu melarutkan hampir semua zat, baik yang bersifat polar, semipolar, dan nonpolar serta dapat menarik senyawa flavonoid secara optimum ${ }^{17}$ Hasil uji kualitatif eksraksi daun kersen menunjukkan positif terdapat saponin, flavonoid, tanin, alkaloid, fenolik dan steroid. Kandungan flavonoid paling dominan pada ekstraksi daun kersen ini yaitu quercetin sebanyak $1.5 \mathrm{mg}$.

Pemberian ekstrak daun kersen (Muntingia calabura L.) pada tikus wistar yang diinduksi etanol 
$40 \%$ selama 30 hari didapatkan derajat kerusakan mukosa dudenum pada kelompok K- berbeda bermakna dibandingkan dengan kelompok K+. Derajat kerusakan mukosa duodenum pada $\mathrm{K}+$ berbeda bermakna dibanding P1 dan P2.

Pada kelompok kontrol negatif(K-) yang diberikan placebo aquadest $1.8 \mathrm{ml} / 200 \mathrm{~g} / \mathrm{KgBB}$ gambaran histologi duodenum memperlihatkan kesan yang normal, tidak didapatkan perubahan patologik pada epitel dan vili-vili duodenum. Hal ini sejalan dengan penelitian sebelumnya bahwa pemberian placebo pada duodenum memberikan gambaran histologi duodenum yang utuh berupa vili yang terdiri dari sel epitelium selapis tersusun rapat dengan inti bulat sampai oval terletak di basal. Kelompok placebo pada penelitian ini tidak diberikan etanol, tetapi aquades. ${ }^{18}$

Hasil perhitungan statistik uji beda rerata derajat kerusakan mukosa duodenum kelompok Kterhadap $\mathrm{K}+$ memberikan hasil berbeda bermakna.Pada kelompok $\mathrm{K}+$ sebagian besar tampak gambaran celah yang mencapai separuh mukosa yang termasuk dalam kategori skor erosi, ditemukan pula adanya deskuamasi serta ulserasi. Hasil ini sejalan dengan penelitian sebelumnya oleh Sommansson (2014)mengenai pemberian ethanol absolute satu kali dalam sehari pada tikus wistar, didapatkan hasil etanol absolut menyebabkan kerusakan parah pada mukosa superfisial dan lesi hemoragik fokal meluas ke dalam mukosa.
Paparan kronis pada konsentrasi etanol sedang dikaitkan dengan perubahan morfologis usus kecil bagian atas termasuk pelepasan epitel dari lamina propria $^{19}$. Penelitian lain yang dilakukan oleh Saroj KS(2016) juga menunjukkan pemberian etanol absolut 1 kali setelah pemberian pakan standar enam hari menghasilkan kerusakan masif berupa ulkus pada duodenum tikus. ${ }^{20}$

Kerusakan yang ditemukan pada kelompok yang diberikan etanol diperantarai oleh radikal bebas. Etanol di dalam duodenum akan diubah menjadi asetaldehid oleh enzim Acetaldehyde dehidrogenase (ADH). Di dalam sel, asetaldehid dalam jumlah besar dapat mengganggu proses transpor elektron, sehingga meningkatkan produksi Reactive oxygen species (ROS), yaitu semacam gugus radikal bebas. Molekul ini dapat mempengaruhi permeabilitas Outer/Inner mithocondrial membrane (OMM/IMM) dan mempengaruhi pembukaan Permeability transition pore (PTP). Gangguan pada permeabilitas membran mitokondria ini menyebabkan mitokondria mengalami edema, sehingga terjadi pembentukan sitokrom C, aktivasi caspase, dan akhirnya fragmentasi DNA. Rangkaian proses ini akan menyebabkan terjadinya apoptosis. Apoptosis yang terjadi pada banyak sel secara sekaligus akan menyebabkan munculnya jejas yang dapat terlihat secara mikroskopis maupun makroskopis, seperti deskuamasi epitel, erosi, hingga ulkus. ${ }^{21}$ 
Perbedaan antara kelompok yang diberikan etanol $40 \%(\mathrm{~K}+)$ terhadap kelompok yang diberikan ekstrak daun kersen dengan dosis $500 \mathrm{mg} / \mathrm{KgBB}(\mathrm{P} 1)$ didapatkan perbedaan hasil yang signifikan pada gambaran histopatologi duodenum. Pada kelompok yang diberikan ekstrak daun kersen dengan dosis 500mg/KgBB (P1) tidak ditemukan adanya perubahan patologik, yang didominasi mukosa dan vili-vili duodenum yang masih utuh. Namun pada beberapa lapang pandang juga ditemukan deskuamasi dan erosi dengan jumlah yang sangat minimal. Kemudian kelompok yang diberikan etanol $40 \%(\mathrm{~K}+)$ terhadap kelompok yang diberikan ekstrak daun kersen dengan dosis yang dilakukan pemberian ekstrak daun kersen dan $750 \mathrm{mg} / \mathrm{KgBB}$ juga didapatkan hasil yang signifikan pada gambaran histopatologi duodenum.Pada kelompok yang diberikan ekstrak daun kersen dengan dosis 750mg/KgBB (P2) gambaran tampak adanya sebagian besar deskuamasi epitel, mukosa dan vili-vili yang juga masih utuh, namun pada beberapa lapang pandang juga ditemukan ulkus dan erosi dengan jumlah yang sangat minimal. Hal ini sesuai dengan penelitian terdahulu yang dilakukan Olayemi KO (2014) mengenai pemberian ekstrak daun kelor (Moringia olifiera) 5 hari, disusul dengan pemberian ethanol absolut pada hari ke 6. Daun kelor merupakan tanaman yang memiliki kandungan yang hamoir sama dengan daun kersen. Kandugan antioksidannya berupa flavonoid, tannin dan saponin telah terbukti memiliki efek hepatoprotektif, anti inflamasi dan efek gastroduodenoprotektif. Kelompok yang diberikan ekstrak daun kelor sebelum pemberian etanol absolute (K-) menunjukkan kerusakan mukosa yang lebih minimal. Hal ini menunjukkan bahwa flavonoid dalam ekstrak daun kelor memiliki efek perlindungan duodenum. Perlindungan tersebut dengan cara memperkuat vili-vili duodenum sehingga tidak mudah terjadi pengelupasan pada mukosa duodenum, ekstrak daun kelor juga terbukti mengurangi produksi asam lambung, yang merupakan salah satu dari faktor agresif duodenum. Penelitian ini melaporkan bahwa kelompok yang hanya diberi etanol absolute satu kali pada hari ke enam $(\mathrm{K}+)$ menunjukkan lesi berupa ulkus yang luas ${ }^{22}$.

Pemberian dosis bertingkat ekstrak daun kersen pada penelitian ini menujukkan respon yang berbanding terbalik dengan efek sitoprotektif yang diberikan. Hal ini terjadi karena komponen senyawa yang terdapat dalam tanaman tidak tunggal melainkan terdiri dari berbagai senyawa kimia yang saling bekerja sama untuk menimbulkan berbagai efek. Kejenuhan resptor diduga juga sebagai salah satu penyebab penurunan respon dalam peningkatan dosis, dimana jenuhnya reseptor yang berikatan dan terjadinya interaksi senyawa kimia yang terkandung dalam tanaman. Jika reseptor telah jenuh, maka peningkatan dosis tidak bisa mencapai efak maksimumnya. ${ }^{21}$ Hasil analisis menunjukkan bahwa peningkatan pemberian 
dosis $500 \mathrm{mg} / \mathrm{KgBB}$ dan $750 \mathrm{mg} / \mathrm{KgBB}$ tidak diikuti dengan efek peningkatan pencegahan kerusakan mukosa duodenum. Penurunan respon ekstrak daun kersen dalam memberikan efek sitoprotektif ditunjukkan dengan adanya peningkatan skor rerata kerusakan mukosa pada dosis $500 \mathrm{mg} / \mathrm{KgBB}$ dan $750 \mathrm{mg} / \mathrm{KgBB}$.

Dosis $500 \mathrm{mg} / \mathrm{kgBB}$ memberikan efek sitoptotektif karena kandungan ekstrak daun kersen mengandung senyawa flavonoid dengan kandungan utamanya adalah quercetin. Flavonoid adalah salah satu kelompok senyawa fenolik yang banyak terdapat pada jaringan tanaman dan dapat berperan sebagai antioksidan. Aktivitas antioksidatif flavonoid bersumber pada kemampuan mendonasikan atom hidrogennya. Flavonoid merupakan antioksidan alam yang mempunyai aktivitas biologis, yaitu sebagai antioksidan yang dapat menghambat berbagai reaksi oksidasi, serta mampu bertindak sebagai pereduksi radikal hidroksil, superoksida, dan radikal peroksil ${ }^{23}$.Dengan adanya efek anti oksidan dari ekstrak daun kersen, kerusakan duodenum akibat radikal bebas yang menimbulkan kerusakan jaringan hingga hancurnya mukosa, apoptosis, dan peradangan diduga dapat dihambat oleh ekstrak daun kersen.

Penelitian ini memiliki beberapa kekurangan, antara lain kurangnya variasi dosis ekstrak daun kersen, kurangnya variasi durasi pemberian ekstrak daun kersen, tidak adanya analisis efek samping yang ditimbulkan, dan tidak adanya pembanding sebelum perlakuan dilakukan. Dengan demikian, peneliti menyarankan agar penelitian berikutnya menambahkan variasi dosis, variasi durasi waktu, menganalisis efek samping, dan menggunakan rancangan Pre test and Post test control group design.

\section{KESIMPULAN}

Pemberian ekstrak daun kersen dengan dosis 500mg/KgBB mampu memberikan efek sitoprotektif pada mukosa duodenum tikus wistar yang diinduksi etanol $40 \%$

\section{DAFTAR PUSTAKA}

1. Kementerian Kesehatan Ri. Riset Kesehatan Dasar Tahun 2018 [Internet]. 2018. Available From:

Http://Labdata.Litbang.Depkes.Go.Id/Riset-

Badan-Litbangkes/Menu-Riskesnas/Menu-

Riskesdas

2. Snowden Fm. Emerging And Reemerging Diseases: A Historical Perspective. Immunol Rev [Internet]. 2008 Oct 1 [Cited 2020 Feb 20];225(1):9-26. Available From: Http://Doi.Wiley.Com/10.1111/J.1600-

065x.2008.00677.X

3. Naghavi M, Wang H, Lozano R, Davis A, Liang X, Zhou M, Et Al. Global, Regional, And National Age-Sex Specific All-Cause And Cause-Specific Mortality For 240 Causes Of Death, 1990-2013: A Systematic Analysis For 
The Global Burden Of Disease Study 2013.

Lancet. 2015 Jan 10;385(9963):117-71.

4. Bhopale Kk, Kondraganti S, Fernando H, Boor

Pj, Kaphalia Bs, Shakeel Ansari Ga. Alcoholic Steatosis In Different Strains Of Rat: A Comparative Study. J Drug Alcohol Res. 2015;

5. Bode C, Watson R, Bode J, Watzl B. Alcohol Malnutrition And The Gastrointestinal Tract. 1992.

6. Zakaria Za, Balan T, Suppaiah V, Ahmad S, Jamaludin F. Mechanism(S) Of Action Involved In The Gastroprotective Activity Of Muntingia Calabura. J Ethnopharmacol. 2014;

7. Pratt D. Natural Antioxidant Exploited Comercially. London: Elsevier Applied Science; 1990.

8. Ninditya D. Pengaruh Ekstrak Daun Kersen(Muntinga Calabura L.) Terhadap Mikroskopik Hepar Tikus Wistar Jantan Yang Diinduksi Etanol Dan Softdrink. J Kedokt Diponegoro. 2016;5(4).

9. $\mathrm{Yu} \mathrm{C}, \mathrm{Mei} \mathrm{Xt}$, Zheng Yp, Xu Dh. Gastroprotective Effect Of Taurine Zinc Solid Dispersions Against Absolute Ethanol-Induced Gastric Lesions Is Mediated By Enhancement Of Antioxidant Activity And Endogenous Pge2production And Attenuation Of No Production. Eur J Pharmacol. 2014 Oct 5;740:329-36.
10. Wahyuni R, Istiadi H, Utomo A. Pengaruh Ekstrak Daun Kersen (Muntingia Calabura L) Terhadap Integritas Mukosa Esofagus Tikus Wistar Yang Diinduksi Etanol Dan Soft Drink [Internet]. 2017 [Cited 2020 Feb 20]. Available From:

Https://Ejournal3.Undip.Ac.Id/Index.Php/Medi co/Article/View/18631

11. Fitria L, Tiraya C. Profil Reproduksi Jantan Tikus (Rattus Norvegicus Berkenhout, 1769) Galur Wistar Stadia Muda, Pradewasa, Dan Dewasa. J Biol Papua. 2015;7(1):29-36.

12. Fitria L. Profil Hematologi Tikus (Rattus Norvegicus Berkenhout, 1769) Galur Wistar Jantan Dan Betina Umur 4, 6, Dan 8 Minggu. Biog J Ilm Biol. 2014;2(2):94-100.

13. Rahmania N. Pengaruh Pemberian Ekstrak

Daun Kelor Terhadap Ketebalan Kornea

Sentral Mencit Yang Diinduksi Sinar

Ultraviolet-C. J Chem Inf Model. 2018;53(9):1689-99.

14. Safitri Ad. Uji Aktivitas Sitotoksik Kombinasi Ekstrak Etanol Kemangi (Ocimum Sanctum L.)

Dan Daun Pepaya (Carica Papaya L.) Terhadap Sel Mcf-7. 2018;

15. Bintari Sg. Temulawak ( Curcuma Xanthorrhiza Roxb ) Sebagai Pencegah

Kerusakan Mukosa Lambung. Majority [Internet]. 2014;3(5):77-84. Available From: 
Http://Juke.Kedokteran.Unila.Ac.Id/Index.Php/

Majority/Article/View/269

16. Bpom Ri. Peraturan Kepala Badan Pengawas Obat Dan Makanan Republik Indonesia Nomor

14 Tahun 2016 Tentang Standar Keamanan

Dan Mutu Minuman Beralkohol. Sekr Negara. 2016;1-17.

17. Puspitasari Ad, Proyogo Ls. Terhadap Kadar Flavonoid Total Ekstrak Etanol Daun Kersen ( Muntingia Calabura. J Farm. 2013;16-23.

18. Djumadi, Hariyatmi. Pengaruh Pemberian Insektisida Diazinon Dan Kurkumin Kunyit (Curcuma Domestica) Per-Oral Terhadap

Perubahan Struktur Histologis Duodenum Mencit (Mus Musculus). 2000;9(1):1-54.

19. Sommansson A, Saudi Wsw, Nylander O, Sjöblom M. The Ethanol-Induced Stimulation

Of Rat Duodenal Mucosal Bicarbonate Secretion In Vivo Is Critically Dependent On Luminal Cl-. Plos One. 2014 Jul 17;9(7).

20. Sahoo A, Mahajan R. Management Of Tinea Corporis, Tinea Cruris, And Tinea Pedis: A Comprehensive Review. Indian Dermatol

Online J. 2016;

21. Wahyudi A, Bahar Y, Septianawati P. Pengaruh Ekstrak Etanol Daun Kemangi ( Ocimum Basilicum L Folium ) Terhadap Kadar Sgot Dan Sgpt Tikus Putih (Rattus Norvegicus Strain Wistar) Yang Diinduksi Msg. Herb-
Medicine J. 2018 Apr 23;1(1).

22. Olaibi K, Olayemi M. Histological And Histomorphometric Studies Of Ethanol-Injured Pylorus And Duodenum Of Wistar Rats PreTreated With Moringa Oliefera Extrac. Vol. 7, Medicine Enlisted Journal • I S S N. 2014.

23. Simanjuntak K. Peran Antioksidan Flavonoid Dalam Meningkatkan Kesehatan. 2012. 